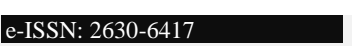

International Academic Social Resources Journal

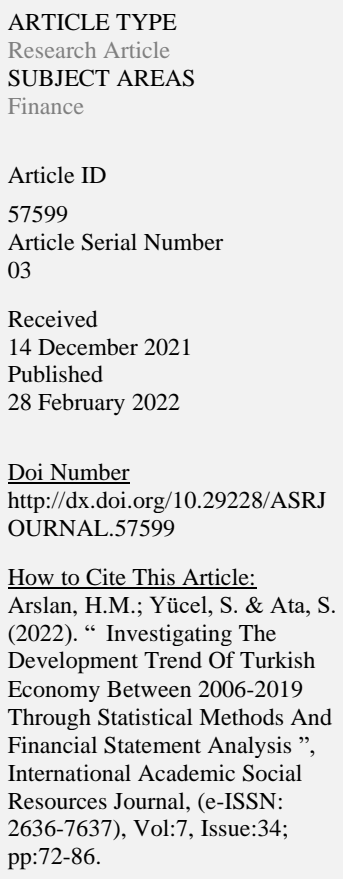

\section{(ब) $(1) \Theta$}

Academic Social Resources Journal is licensed under a Creative Commons Attribution-NonCommercial 4.0 Attribution-NonCommer
International License.

\title{
Investigating The Development Trend Of Turkish Economy Between 2006- 2019 Through Statistical Methods And Financial Statement Analysis
}

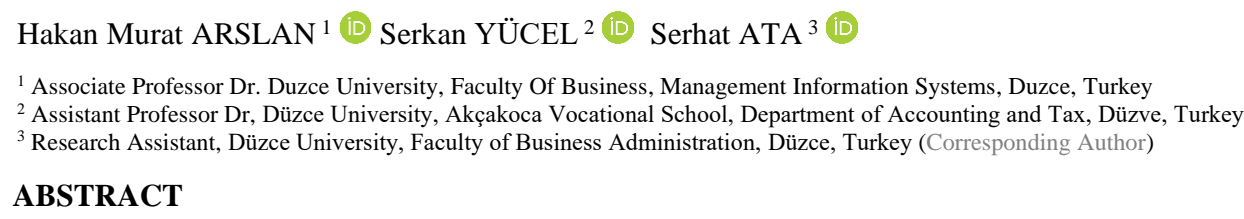

\section{ABSTRACT}

The aim of this study is to examine the economic development of the Republic of Turkey in the last 14 years. For this purpose, the basic financial table data of the manufacturing industry companies that form the basis of the Turkish economy and the change in the number of companies in the sector between 2006-2019 were analyzed. The data used in the study are obtained from the Entrepreneur Information System of the T.C. Ministry of Industry and Technology. The data obtained were analyzed by trend analysis, one of the financial statement analysis methods. Mann Kendall and Regression Analysis methods were used in trend analysis. In addition, financial forecasts for the next four years were made using the Time Series Analysis method. As a result of the assessment, it was determined that while significant financial breakdowns were experienced in the financial statement data of Turkish manufacturing industry enterprises between 2008, 2011 and 2018, inversely proportional to inflation, these data were generally in an upward trend.

Keywords: Manufacturing Industry Enterprises, Financial Statement Analysis, Trend Analysis, Mann Kendall Trend Analysis, Regression Analysis

\section{INTRODUCTION}

Today, private sector industrial organizations determine the economic development level of many countries where liberal policies are dominant in the world. It is possible to understand the financial power of these institutions from their financial statements. Financial statements reveal the past and current situation of the enterprises, as well as provide the opportunity to make predictions for the future. There are many methods used in financial statement analysis and one of these methods is the trend percentages (Trend Analysis) method.

With the percentages of trend (trend analysis) method, the trends of the items in the financial statements over time are analyzed. In this analysis technique, a dynamic analysis is carried out by clearly revealing the percentile importance of the increase or decrease related the items in the financial statements between certain dates and periods. Thus, by comparing the trends of the items in the financial statements, it is possible to reach conclusions about the positive or negative developments in the review period (Usta 2008: 139).

In this study, it is aimed to determine the change in the financial structure of the manufacturing industry in the 14year period and to make predictions for the future by evaluating the basic financial statement data of the 12 subgroups of the manufacturing sector, which forms the basis of the Turkish economy, between the years 2006-2019 with "Trend" and "Regression Analysis". For this purpose, "profit before tax" and "business total assets" data from the financial statements were examined. In addition, the "number of businesses" in the sectors was included in the scope of the analysis in order to better understand the development of the manufacturing industry. The evaluation is based on the acceptance or rejection of the hypotheses. The main expectation from the research is to determine whether the Turkish economy is systematically affected by some socio-economic events in certain years.

Mann-Kendal Trend Analysis was used in the evaluation of the hypotheses in the study. Regression Analysis was used to confirm the reliability of the results and it was determined that the findings overlapped. In addition, 20202023 data was estimated by Time Series Analysis Methods by making use of current data.

What makes the study different from similar studies in the literature is that the study took place in the entire Turkish universe and that the study that applied Mann-Kendal Trend Analysis and Regression Analysis methods to the financial data used in the study is not in the literature. With these aspects, the study is an original and is expected to fill a deep gap in the relevant literature.

The following sections of the study are structured as follows. In the second part, a detailed literature review of the research subject is given. In the third part, the structure of the data used and the adequacy of the analysis methods 
used to achieve the determined purpose are described methodologically. In the fourth part, the findings of the research and related comments are expressed. In the last part, the results of the research are given and the results are compared with the results of previous similar studies

\section{LITERATURE REVIEW}

In this section, academic studies related to the subject of the study are presented. Within the scope of trend analysis in Turkey, it is seen that the Mann Kendal method is used for seasonal purposes such as temperature changes, precipitation trends, changes in stream flow, and some of the studies that can be detected are as follows:

Karabulut and Cosun (2007) investigated annual, seasonal and monthly precipitation trends for meteorology stations in Kahramanmaraş, located in the Mediterranean Region, between 1975 and 2005. In the study, together with the Mann-Kendall method; Precipitation trends were analyzed using statistical methods such as linear regression, precipitation variability, and coefficient of variation. In the study of Saplığlu et al. (2018), the trends of monthly and annual precipitation data in the Somaliland region in the North of Somalia in Africa, which is one of the regions most affected by climate change, were examined. For this purpose, the statistical method proposed by Saplioğlu, based on Mann-Kendall trend analysis, and Şen graph test, was used for this purpose. Citakoğlu and Minarecioğlu (2019) conducted a trend analysis using the monthly average flow values obtained from three different flow observation stations in the Kizllirmak basin and investigated the presence of a significant trend. For this purpose, Mann Kendall, Modified Mann Kendall, Spearman's Rho and Linear regression methods were used together as analysis methods. Dalk1lıç (2019) in his study aimed to determine the precipitation trends in the region with the data between 1978 and 2018 belonging to the provinces of Gümüşhane, Erzincan, Bayburt, whose precipitation structure is parallel to each other. Sen trend test, Spearman Rho, Mann-Kendall tests were used to determine the presence of trend. In other study, İlker and Terzi (2020) applied trend analysis to determine monthly temperature changes in eight city centers in the Kiz1lirmak basin, Turkey's second largest basin. The trend analysis was carried out with the Mann-Kendall test, using data from the 38-year period between 1980-2017, obtained from the General Directorate of State Meteorology Affairs. Sen's trend test was used to determine the amount of change.

Apart from these studies, there are also studies in which various regression models are used to examine the development of economic events within the scope of train analysis. Some of them are as follows:

Çiçek and Doğan (2018) made price predictions for the period of 2018-2020 within the scope of trend analysis, using live cattle and beef imports in Turkey in 2010-2016, current feed and beef producer prices in 1998-2017, and monthly producer prices index. In the analyzes made, linear, quadratic, exponential, and s-curve trend models in Minitab 17.1.0 program were tested. Y1ldırım and Birecikli (2021) tried to determine the household savings tendency in Turkey by using the data set of the 2003-2013 Household Budget Surveys conducted by the Turkish Statistical Institute (TUIK). One of the striking findings of the study, in which Regression in Tranche method was used, is that the trend of household savings, which showed a positive trend until 2008, changed negatively after 2008 due to the cyclical uncertainties and low interest policy implementations. Avc1 and Sulak (2015) examined the relations between economic growth and selected economic indicators using regression trees and least-square method during the crisis periods between 1990-2010 in Turkey. According to the findings of the study, significant decreases were detected in economic growth figures, as expected, during the 1994, 2001 and 2008 economic crisis periods, which were included in the years within the scope of the study, with both analysis methods.

Some of the studies that can be found to use Trend Analysis in Financial Statement Analysis in Turkey are given below;

Özgülbaş (2006) used trend analysis method to evaluate the financial status of public hospitals in Turkey. In this study, Özgülbaş (2006) analyzed the changes in the financial ratios obtained from the five-year financial statements of public hospitals for the years 1996-2000 using trend analysis. Güngörmüş (2007) analyzed the financial statements of Emet Municipality using trend analysis method. In the study, the change in the revenues and expenditures of Emet Municipality between the years 1995-2000 is discussed. Kirac1 and Karaaslan (2015) evaluated the financial data obtained from the financial statements of the five major European-based airline companies, including Turkish Airlines, for the period 2009-2014, using the trend analysis method. In the study, interpretations have been made by considering the bilateral relations of nine separate account items. Sargut (2018) analyzed the financial statements of Eregli Demir Çelik A.Ş for the years 2012-2016 with the trend analysis method. In the study, the development of the company's current-fixed asset, short-term, long-term foreign resource-equity structure and the change in sales profitability in the mentioned years were examined. Ercan and Şenbayram (2018) analyzed the financial statements of an agricultural sector enterprise traded in BIST for the period 2013-2017 using Trend Analysis (trend percentages) method. In the study, the changes in some financial statement items such as "stocks-net sales", which are related to each other, are examined.

As can be understood from the studies above, the Trend Analysis method within the scope of financial statement analysis in Turkey has been made in the form of a comparison between years and has been supported by any 
statistical method. In the world, within the scope of Trend Analysis, one of the financial statement analysis methods, the studies that have been determined to analyze the data with statistical methods are as follows:

Valášková et al. (2020) analyzed the 2010-2018 Earnings Before Interest, Taxes,Depreciation and Amortization (EBITDA) of businesses in Visegrad Group Countries (Slovakia, Czech Republic, Poland, and Hungary) using the Trend Analysis method. In this study, Jarque-Bera test, Shapiro-Wilk test, Anderson-Darling test, Lilliefors test and Box-Pierce test were used. Durana and Bacik (2020) tried to determine the changes in the tendencies of managers on earnings management. For this purpose, they researched a nine-year period from 2010 to 2018 in Visegrad Group countries businesses, they used non-parametric time series trend modeling, Mann-Kendall Test and Sen's trend method in their studies. In this study, Valášková et al. (2020), earnings before interest, tax, depreciation, and amortization (EBITDA) of enterprises were examined. Kliestik et al. (2020) tried to determine the development of earnings management in Visegrad Group countries by using the Trend Analysis method, similar to Durana and Bacik (2020). In the study, the change in the profits before interest and depreciation (EBITDA) of the companies between 2009 and 2018 was tried to be determined by Mann Kendal and Buishand Test.

\section{METHODOLOGY}

The aim of this study is to examine the development of the manufacturing industry sector in Turkey in the last 14 years (2006-2019) with Trend Analysis and Regression Analysis methods and to make predictions for the near future with Time Series Analysis Method. For this purpose, the financial table data of the sectors were obtained from the Entrepreneur Information System of the Ministry of Industry and Technology of Turkey

A three-stage path was followed in the analysis of the research. Based on the data obtained, hypotheses about whether there is a systematic trend in the data were constructed and tested with the Mann-Kendall Trend Analysis method. In the second stage, Regression Analysis was used to determine the direction of the trend in the data. In the third stage, based on the overlapping trend results in the first two steps, predictions for the near future were made using the Time Series Analysis method.

\subsection{Limitations of the Study}

In the Entrepreneur Information System of the Ministry of Industry and Technology of Turkey, where the financial statement data used in the research is provided, the manufacturing sector is classified under 22 sub-headings, and it has been observed that the " Earnings Before Interest, Tax, Depreciation, and Amortization " information is clearly reported in the financial statements of 12 of these sectors. For this reason, 12 sectors with full data were included in the research. This date range has been taken into account in the research, as data for the years 2006-2019 (14 years) are presented in the Entrepreneur Information System of the Ministry of Industry and Technology of Turkey as of the period of May-2021, when the study was conducted.

\subsection{Methods Used in the Analysis}

\subsubsection{Mann-Kendal Trend Analysis Method}

Known as Kendall's Tau statistic, the test is generally used to detect different trends in meteorological time series such as temperature and precipitation (Büyükkaraciğan, 2019; Yue et al., 2002). In the Mann-Kendall test, the observations were ordered by time. In the $\mathrm{H}_{0}$ hypothesis, they are considered time-independent and similarly distributed random variables ( $\mathrm{Yu}$ et al., 1993). In the $\mathrm{H}_{1}$ hypothesis, the $\mathrm{xk}$ and $\mathrm{xj}$ values in the series showed different distribution for all $(\mathrm{k}, \mathrm{j} \leq \mathrm{n})$, including $(\mathrm{k} \neq \mathrm{j})$. That is, there is a linear trend in the series. The statistics $(\mathrm{S})$ of this test, which is applied without considering seasonality, are calculated with the following formulas.

$$
S=\sum_{k=1}^{n-1} \sum_{j=k+1}^{n} \operatorname{sgn}\left(x_{j}-x_{k}\right)
$$

$$
\operatorname{sgn}\left(x_{j}-x_{k}\right)=\left\{\begin{array}{rll}
+1 & \text { if } & \left(x_{j}-x_{k}\right)>0 \\
0 & \text { if } & \left(x_{j}-x_{k}\right)=0 \\
-1 & \text { if } & \left(x_{j}-x_{k}\right)<0
\end{array}\right\}
$$

The variance of the test statistic (S) of the series that exhibits a normal distribution and has a zero arithmatic mean is calculated with the formula $\operatorname{Var}(S)=n(n-1)(2 n+5) / 18$. If there is a tie between the elements of the series, the value $\Sigma t(t-1)(2 t+5)$ is subtracted from the numerator of this formula. Here, the $t$ value represents the number of $x$ 's in the tie between the elements of the series, and $\Sigma t(t-1)(2 t+5)$ the sum of all the ties (Hirsch et al., 1982). As a result, the standard normal variable $(\mathrm{z})$ is calculated with the formula given below and compared with the critical $\mathrm{z}$ value. 
$\mathrm{z}=\left\{\begin{array}{clc}\frac{\mathrm{S}-1}{\sqrt{\operatorname{Var}(\mathrm{S})}} & \text { if } & \mathrm{S}>0 \\ 0 & \text { if } & \mathrm{S}=0 \\ \frac{\mathrm{S}+1}{\sqrt{\operatorname{Var}(\mathrm{S})}} & \text { if } & \mathrm{S}<0\end{array}\right\}$

If the inequality $|\mathrm{z}| \leq \mathrm{z}_{-}(\propto / 2)$ is satisfied at the significance level $\propto$, the $\mathrm{H}_{0}$ hypothesis is accepted, otherwise it is rejected. If the $\mathrm{S}$ value is positive, it can be said that there is an increasing trend, and if it is negative, there is a decreasing trend. This test technique is useful for calculating the trend of series that do not take into account incomplete-inaccurate data and do not show a certain distribution (Yu et al., 1993).

\subsubsection{Regression Analysis}

Regression analysis is a method used to evaluate the relationship between two or more quantitative variables. If the analysis is performed using a single independent variable, it is called univariate regression, if the analysis is performed using more than one independent variable, it is called multivariate regression analysis. Thanks to the regression analysis, information about the existence of the relationship between dependent and independent variables and, if any, the strength of the relationship can be obtained (Gujarati \& Damodar, 2008). In the Linear Regression model, it is assumed that the independent $\mathrm{Xi}$ variables are measured without error and the dependent variable $\mathrm{Y}$ is calculated by taking into account a certain error (ci ) rate (Cengiz and Terzi, 2020).

The existence of a linear relationship between the independent variable $\mathrm{X}$ and the dependent variable $\mathrm{Y}$ means that the relevant parameters are in a linear relationship in the regression model rather than the linearity of the relationship curve.

$$
\begin{aligned}
& E(Y)=\beta_{0}+\beta_{1} X \Rightarrow E(Y \mid X)=\beta_{0}+\beta_{1} X \\
& Y \sim N\left(\beta_{0}+\beta_{1} X, \sigma^{2}\right) \\
& \hat{Y}=E(\hat{Y})=\hat{\beta}_{0}+\hat{\beta}_{1} X \\
& Y_{i}=\beta_{0}+\beta_{1} X_{i}+\varepsilon_{i} \quad, i=1,2, \ldots, n
\end{aligned}
$$

In the equations above;

$\beta_{0}$ : The point where the line intersects the $\mathrm{Y}$ axis,

$\beta_{1}$ : Indicates the regression coefficient. Considering these data, Ho and $\mathrm{H} 1$ hypotheses are established.

\subsection{Time Series Analysis}

Time series are series ordered by time. The rows of this series are periodically composed of time slots. Time series can be defined as simple series in which events and processes that can be digitized can be explained with a time cycle (https://productphilosophy.com/zaman-serisi-analizi/). Time Series Analyzes are performed with different methods classified as; Simple Average Method, Moving Averages Method, Exponential Smoothing Method, Trend Analysis Method, and Seasonal Fluctuations and Trend Ratio Method (Yavuz, 2020).

Since Trend Analysis method is applied in the study, this analysis type is explained. The only difference of this method from simple linear regression analysis is that the independent variable $\mathrm{X}$ expresses time. As in the simple linear regression method, in this method, the $a$ and $b$ coefficients are calculated and the equation $\mathrm{Y}=\mathrm{a}+\mathrm{bX}$ is formed. The coefficients of the Y linear equation are found by the formulas given below.

Since Trend Analysis method is applied in the study, this analysis type is explained. The only difference of this method from simple linear regression analysis is that the independent variable $\mathrm{X}$ expresses time. As in the simple linear regression method, in this method, the $a$ and $b$ coefficients are calculated and the equation $\mathrm{Y}=\mathrm{a}+\mathrm{bX}$ is formed. The coefficients of the Y linear equation are found by the formulas given below.

$$
a=\frac{\sum_{i=1}^{n} Y_{i}-b \sum_{i=1}^{n} X_{i}}{n} \quad b=\frac{\left(n \sum_{i=1}^{n} X_{i} Y_{i}\right)-\left(\sum_{i=1}^{n} X_{i} \sum_{i=1}^{n} Y_{i}\right)}{\left(n \sum_{i=1}^{n} X_{i}{ }^{2}\right)-\left(\sum_{i=1}^{n} X_{i} \sum_{i=1}^{n} X_{i}\right)}
$$




\section{FINDINGS}

\subsection{Conducting Hypotheses for the Trend of Data}

For applying the Mann-Kendal Trend Analysis and Regression Analysis methods, first of all, hypotheses must be formed. In the study, in order to monitor the financial development of the sectors; Ho and H1 hypotheses were formed separately for each of the elements determined as "Net Profit Before Tax", "Total Asset Size" and "Number of Businesses". In this respect, the following basic hypotheses are included in the study;

$\mathbf{H}_{\mathbf{0}}$ : There is no systematic trend in the data of the determined manufacturing sector for the years 2006-2019.

$\mathbf{H}_{1}$ : There is a systematic trend in the data of the determined manufacturing sector for the years 2006-2019.

\subsection{Evaluation of Hypotheses by Mann-Kendal Trend Analysis and Regression Analysis Method}

The results of the Trend and Trend Analysis conducted regarding the financial statement data of the Turkish manufacturing industry sub-sectors between the years 2006-2019 are as seen in the tables below. The basic data sets used in the implementation of Mann- Kendal Train Analysis and Regression Analysis are expressed in the appendices at the end of the study (Annex:1, Annex: 2 and Annex: 3).

Table 1: Mann- Kendal Trend Analysis and Regression Analysis of Net Profit Before Tax

\begin{tabular}{lccccccc}
\hline & \multicolumn{2}{c}{ Result of Mann- Kendal Trend Analysis } & \multicolumn{2}{c}{ Result of Regression Analysis } \\
\hline & Var(S) & $\mathbf{S}$ & $\mathbf{Z r}$ & Result & Slope & $\mathbf{R}^{\mathbf{2}}$ & Trend by Slope \\
\hline FOOD & 334 & 1,00 & 0,000 & No Systematic Trend & 0,0072 & 0.417 & On the Increase \\
\hline CLOTHING & 334 & 5,00 & 0,219 & No Systematic Trend & 0,0095 & 0,692 & On the Increase \\
\hline CHEATHER & 334 & 3,00 & 0,109 & No Systematic Trend & 0,0056 & 0,436 & On the Increase \\
\hline PLASTIC & 334 & 5,00 & 0,219 & No Systematic Trend & 0,0143 & 0,786 & On the Increase \\
\hline MiNERAL & 334 & 5,00 & 0,219 & No Systematic Trend & 0,0103 & 0,746 & On the Increase \\
\hline METAL & 334 & $-3,00$ & $-0,109$ & No Systematic Trend & $-0,0009$ & 0,018 & On the Decrease \\
\hline ELECTRICITY & 334 & 5,00 & 0,219 & No Systematic Trend & 0,0102 & 0,822 & On the Increase \\
\hline MACHINE & 334 & $-1,00$ & 0,000 & No Systematic Trend & 0,0056 & 0,705 & On the Increase \\
\hline OTOMOTIVE & 334 & 5,00 & 0,219 & No Systematic Trend & 0,0095 & 0,777 & On the Increase \\
\hline OURNITURE & 334 & 5,00 & 0,219 & No Systematic Trend & 0,0098 & 0,818 & On the Increase \\
\hline OTHER INDUSTRIES & 334 & 3,00 & 0,109 & No Systematic Trend & 0,0050 & 0,538 & On the Increase \\
\hline
\end{tabular}

When Table 1 is examined; according to the results of the Mann-Kendall Trend Analysis method applied to the pretax net profit data for the years 2006-2019, it is seen that the critical z values ( $\mathrm{Zr}$ ) at $95 \%$ confidence level are between -1.96 and 1.96. This result means that the $\mathrm{H} 0$ hypothesis is accepted, that is, there is no systematic trend of the manufacturing sector net profit before tax data between 2006-2019.

However, when we look at the results of the Regression Analysis in the table, it is seen that there is a positive trend in all sectors except the Mineral Sector. This shows that the profit before tax of the sectors in general are on a continuous increase trend from 2006 to 2019.

Table 2: Mann- Kendal Trend Analysis and Regression Analysis of Asset Size

\begin{tabular}{lccccccc}
\hline & Result of Mann- Kendal Trend Analysis & \multicolumn{3}{c}{ Result of Regression Analysis } \\
\hline & Var(S) & $\mathbf{S}$ & $\mathbf{Z r}$ & Result & Slope & $\mathbf{R}^{\mathbf{2}}$ & Trend by Slope \\
\hline FOOD & 334 & 13,00 & 0,657 & No Systematic Trend & 0,0067 & 0,921 & On the Increase \\
\hline CLOTHING & 334 & 13,00 & 0,657 & No Systematic Trend & 0,0067 & 0,969 & On the Increase \\
\hline LEATHER & 334 & 11,00 & 0,547 & No Systematic Trend & 0,0086 & 0,653 & On the Increase \\
\hline CHEMICAL & 334 & 13,00 & 0,657 & No Systematic Trend & 0,0108 & 0,853 & On the Increase \\
\hline PLASTIC & 334 & 13,00 & 0,657 & No Systematic Trend & 0,0103 & 0,926 & On the Increase \\
\hline MINERAL & 334 & 13,00 & 0,657 & No Systematic Trend & 0,0073 & 0,961 & On the Increase \\
\hline METAL & 334 & 11,00 & 0,547 & No Systematic Trend & 0,0067 & 0,96 & On the Increase \\
\hline ELECTRICITY & 334 & 13,00 & 0,657 & No Systematic Trend & 0,0071 & 0,926 & On the Increase \\
\hline MACHINE & 334 & 13,00 & 0,657 & No Systematic Trend & 0,0087 & 0,874 & On the Increase \\
\hline OTOMOTIVE & 334 & 13,00 & 0,657 & No Systematic Trend & 0,0089 & 0,925 & On the Increase \\
\hline FURNITURE & 334 & 13,00 & 0,657 & No Systematic Trend & 0,0072 & 0,988 & On the Increase \\
\hline OTHER INDUSTRIES & 334 & 13,00 & 0,657 & No Systematic Trend & 0,0103 & 0,928 & On the Increase \\
\hline
\end{tabular}

When Table 2 is examined; according to the results of the Mann-Kendall Trend Analysis method applied to the asset size data of the years 2006-2019, it is seen that the critical $\mathrm{z}$ values $(\mathrm{Zr})$ at $95 \%$ confidence level are between -1.96 and 1.96. This means that the $\mathrm{H} 0$ hypothesis was accepted for asset sizes as well as profit before tax, that is, between the years of 2006-2019, T.C. It means that there is no systematic trend in the asset size data of the Manufacturing Sector.

In addition, looking at the results of the Regression Analysis in the table, it is seen that there is a positive trend in all sectors. This shows that the asset sizes of all sectors are in a continuous increase trend from 2006 to 2019. In other words, the Turkish manufacturing industry has grown in terms of volume in the last 14 years. However, when the 
inflation rates in Turkey are taken into account, it cannot be predicted exactly to what extent the real growth is realized from these findings.

Table 3: Mann- Kendal Trend Analysis and Regression Analysis Results of the Number of Businesses

\begin{tabular}{lccccccc}
\hline & \multicolumn{1}{c}{ Result of Mann- Kendal Trend Analysis } & \multicolumn{3}{c}{ Result of Regression Analysis } \\
\hline & Var(S) & $\mathbf{S}$ & $\mathbf{Z r}$ & Result & Slope & $\mathbf{R}^{\mathbf{2}}$ & Trend by Slope \\
\hline FOOD & 334 & 13,00 & 0,657 & No Systematic Trend & 0,0038 & 0,985 & On the Increase \\
\hline CLOTHING & 334 & 9,00 & 0,438 & No Systematic Trend & 0,0029 & 0,911 & On the Increase \\
\hline LEATHER & 334 & 9,00 & 0,438 & No Systematic Trend & 0,0019 & 0,916 & On the Increase \\
\hline CHEMICAL & 334 & 1,00 & 0,000 & No Systematic Trend & $-0,0004$ & 0,469 & On the Decrease \\
\hline PLASTIC & 334 & 13,00 & 0,657 & No Systematic Trend & 0,0031 & 0,989 & On the Increase \\
\hline MíNERAL & 334 & 13,00 & 0,657 & No Systematic Trend & 0,0025 & 0,972 & On the Increase \\
\hline METAL & 334 & 11,00 & 0,547 & No Systematic Trend & 0,0047 & 0,964 & On the Increase \\
\hline ELECTRICITY & 334 & 13,00 & 0,657 & No Systematic Trend & 0,0037 & 0,985 & On the Increase \\
\hline MACHINE & 334 & 13,00 & 0,657 & No Systematic Trend & 0,0032 & 0,981 & On the Increase \\
\hline OTOMOTIVE & 334 & 5,00 & 0,219 & No Systematic Trend & 0,0013 & 0,885 & On the Increase \\
\hline FURNITURE & 334 & 13,00 & 0,657 & No Systematic Trend & 0,0045 & 0,958 & On the Increase \\
\hline OTHER INDUSTRIES & 334 & $-1,00$ & 0,000 & No Systematic Trend & $-0,0028$ & 0,728 & On the Decrease \\
\hline
\end{tabular}

When Table 3 is examined; According to the results of the Mann-Kendall Trend Analysis method applied to the data of the number of businesses in the sectors for the years 2006-2019, it is seen that the critical z values (Zr) at $95 \%$ confidence level are between -1.96 and 1.96. These findings mean that the $\mathrm{H} 0$ hypothesis is accepted for the number of enterprises in the sectors, as in the previous two analyzes, that is, there is no systematic trend in the data of the number of enterprises in the Manufacturing Sector between the years 2006-2019. However, when the Regression Analysis results in the table are examined, it is seen that there is a positive trend except for the Chemical and Other Manufacturing sectors. This shows that the number of enterprises in the vast majority of sectors is on a continuous increase trend from 2006 to 2019.

As it can be understood from the tables and explanations above, it has been understood that there is no systematic trend in the last 14 years (between 2006-2019) in the data of profit before tax, asset size figures and number of enterprises selected from the financial statements of the Turkish manufacturing industry with Mann Kendal Trend Analysis. However, when the data are analyzed by Regression Analysis, it is possible to express how the trend directions differ, that is, the direction of the trends on a sectoral basis, despite the absence of a systematic trend. These findings are very important in terms of future projections.

\subsection{Annual Inflation Rates for the Research Period (2006-2019)}

In order to better understand the analysis results applied to the data obtained from the financial statements of the manufacturing sector, the Consumer Price Index (CPI) and Producer Price Index (PPI) rates that occurred in Turkey between the years 2006-2019 are given in the table below.

Tablo 4: CPI and PPI Rates between 2006-2019

\begin{tabular}{|c|c|c|}
\hline & CPI & PPI \\
\hline 2006 & 9,65 & 11,58 \\
\hline 2007 & 8,39 & 5,94 \\
\hline 2008 & 10,06 & 8,11 \\
\hline 2009 & 6,53 & 5,93 \\
\hline 2010 & 6,4 & 8,87 \\
\hline 2011 & 10,45 & 13,33 \\
\hline 2012 & 6,16 & 2,45 \\
\hline 2013 & 7,4 & 6,97 \\
\hline 2014 & 8,17 & 6,36 \\
\hline 2015 & 8,81 & 5,71 \\
\hline 2016 & 8,53 & 9,94 \\
\hline 2017 & 11,92 & 15,47 \\
\hline 2018 & 20,3 & 33,64 \\
\hline 2019 & 11,84 & 7,36 \\
\hline 2020 & 14,6 & 25,15 \\
\hline
\end{tabular}

When the data in Table 4 is examined; it is observed that inflation reached double-digit figures in 2008 and 2011 in Turkey. However, it is clearly seen that 2018 was the most economically fragile time period among the examined years. 


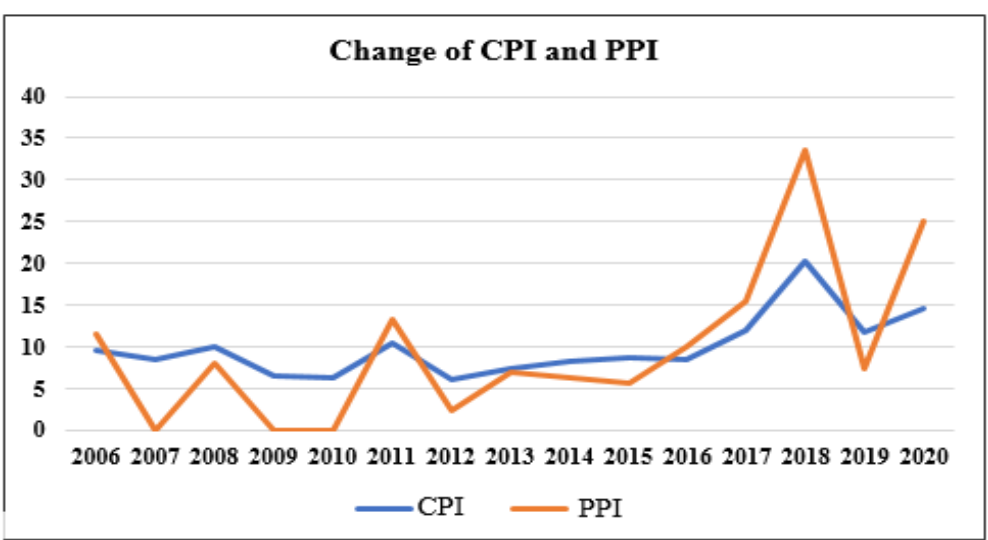

Figure 1: Change of CPI and PPI Between 2006-2019

When Figure 1 is examined; As in Table 4, it is visually understood that there were serious increases in inflation levels in 2008, 2011 and 2018. It can be said that these years were the years when inflation rates, which had a horizontal trend in Turkey, experienced serious breaks.

\subsection{Trend Curves of Manufacturing Sub-sectors for the Research Period}

In the tables in this section, slope measurement and R2 values are given. These values were obtained from the linear regression equations $(\mathrm{Y}=\mathrm{a}+\mathrm{bx})$. As it is known, $\mathrm{R} 2$ values are an indicator of the extent to which the independent variables explain the dependent variables. Dependent variables in the study are net profit before tax, asset size and number of businesses, respectively. The independent variable was chosen as time in each.

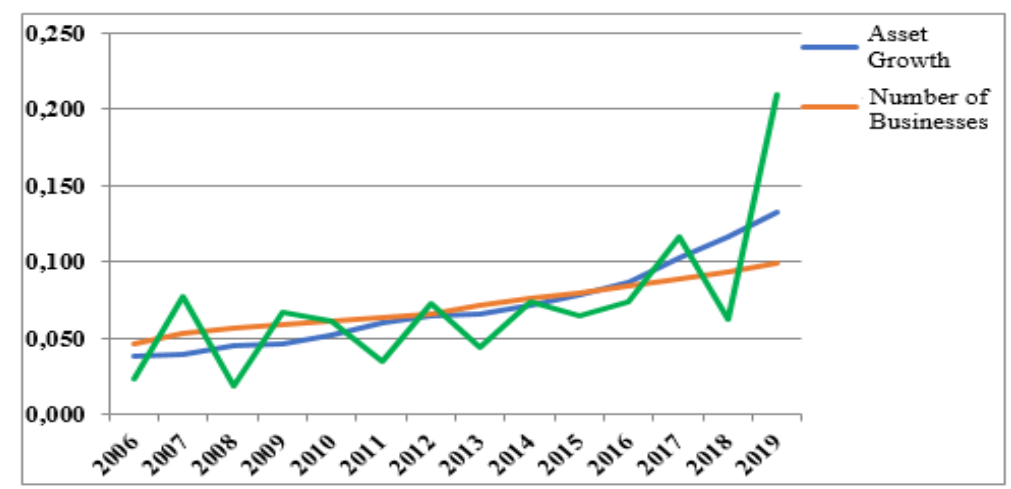

Figure 2: Trend Curves of the Food Industry Between 2006-2019

When Figure 2 is examined carefully; Regarding the average pre-tax profits of businesses belonging to the Food Sector, the following points are noteworthy:

$\checkmark$ A significant decline in profit before tax data is striking in 2008 .

$\checkmark$ There is a decrease in 2011 and 2013, although not as much as in 2008.

$\checkmark$ While an upward trend started with a partial decrease in 2015, a sharp decrease occurred in 2018.

When these determinations are compared with the CPI-PPI graph expressed in the previous section; It can be said that it coincides with the economic activity that occurred especially in 2008, 2011 and 2018.

When the asset size and the number of enterprises in the sector are examined, it is not possible to make a clear determination as much as the profit before tax. However, it can be said that the effect of the economic troubles in 2008 and 2011 in terms of data was partially felt in the following years, that is, it caused a slowdown in the growth trend.

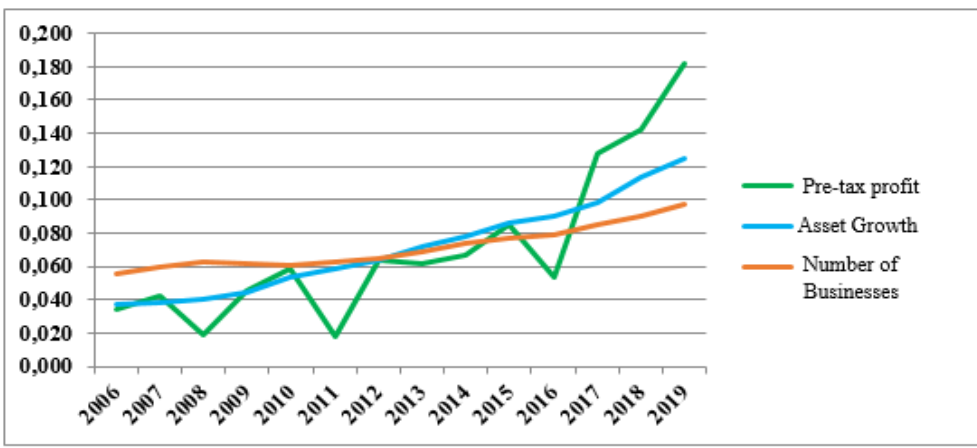

Figure 3: Trend Curves of the Clothing Industry Between 2006-2019 
When Figure 3 regarding the clothing sector is examined; It has been determined that the effect of 2008, similar to the food sector, was seen in 2011, but there was a decrease in profitability between the years 2015-2016. In addition, the upward trend is clearly seen when looking at the chart as a whole.

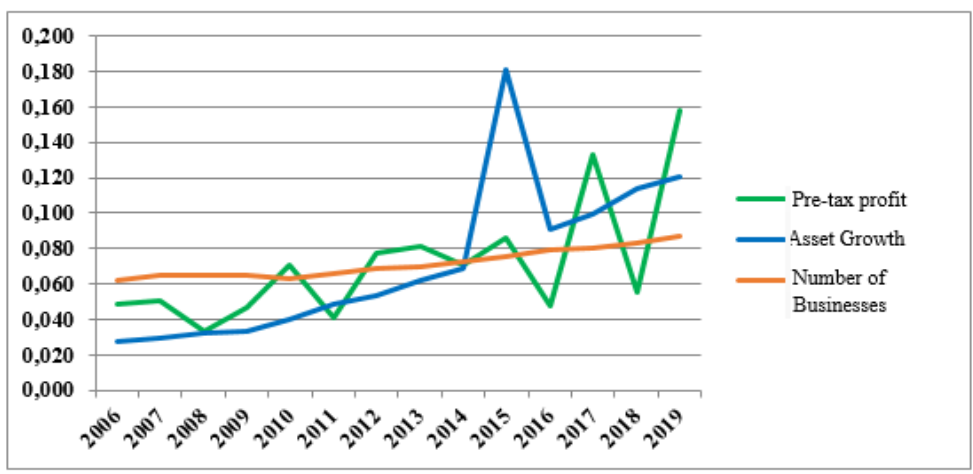

Figure 4: Trend Curves for the Leather Industry Between 2006-2019

When Figure 4 of the leather sector is examined; Similar to the previous two sectors, the impact of financial disruptions on profitability can be seen in 2008, 2011 and 2018. However, unlike the others, a remarkable situation was observed in the graphic. That is, in 2015, unlike other sectors, there was a serious decrease in profits in the leather industry. In the research conducted on this situation, it has been seen that the tension in Turkish-Russian relations due to the plane crash that took place in 2015 with Russia, where Turkey carries out a large part of its leather exports, has a great impact (Haberrus, 2015). In addition, no reason was found in the analysis of the sudden rise and fall in the asset size in 2015-2016.

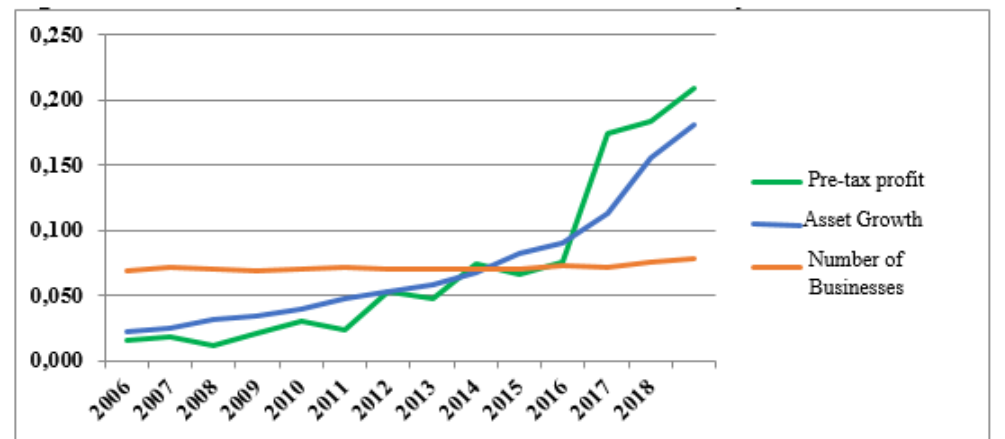

Figure 5: Trend Curves for the Chemical Products Industry Between 2006-2019

When the graphic above regarding the chemicals sector is examined, the effects of the financial crisis in 2018, 2011 and 2013 are partially seen, but a significant growth is observed in the chemical products sector in 2016 and after, unlike other sectors. It is noteworthy that the number of enterprises operating in the sector has followed a horizontal course in 14 years, but there has been a decrease between 2014 and 2018.

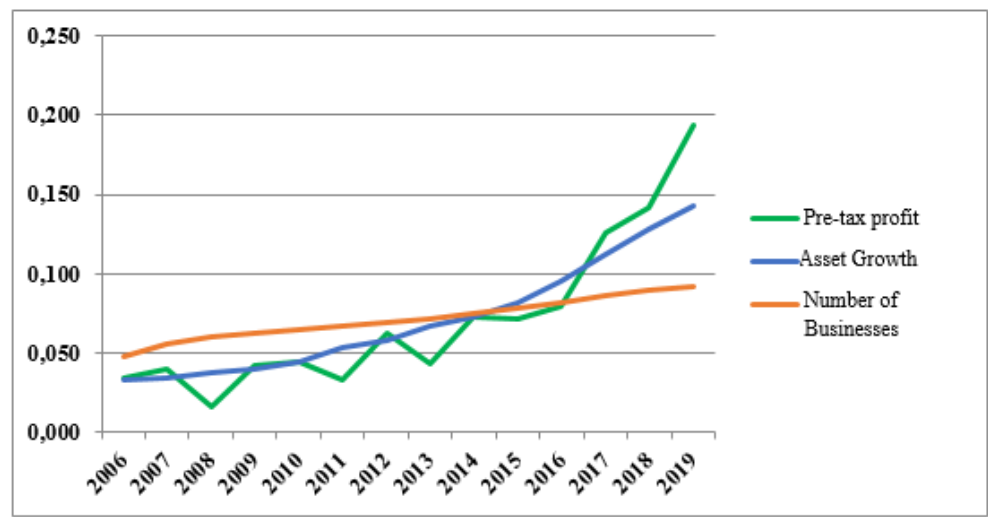

Figure 6: Trend Curves of the Rubber and Plastic Products Industry Between 2006-2019

When the graphic above regarding the Rubber and Plastics sector is examined, the effects of the financial crisis in 2008, 2011 and 2013 are seen, as in other sectors. However, it is seen that the growth trend continued in 2016 and beyond, similar to the Chemical industry, and there was no decline in 2018. 


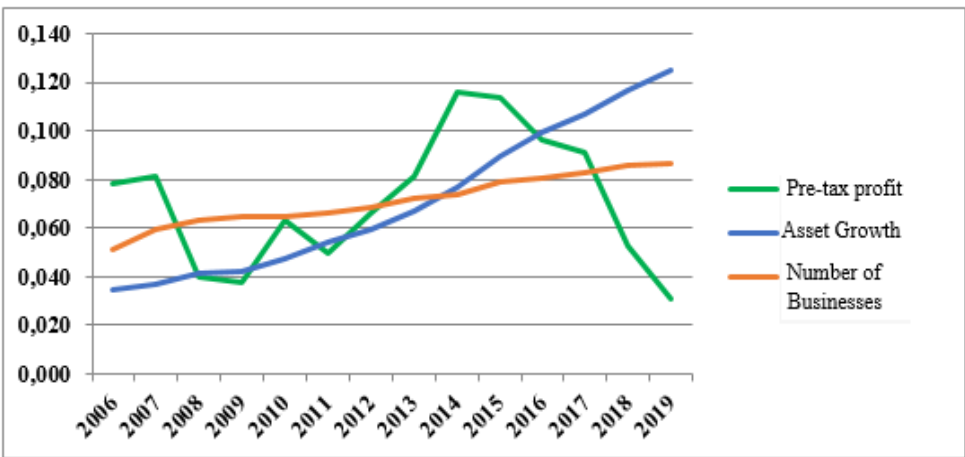

Figure 7: Trend Curves for the Mineral Industry Between 2006-2019

When the figure above regarding the mineral sector is examined; It draws attention to a very different view from the previously evaluated sectors. Although the profitability declines in 2008 and 2011 were similar to other sectors, it was determined that the sector entered a serious downward trend after 2014.

In the research conducted on the subject, it has been understood that the companies producing in the mineral sector are the companies that supply raw materials to the construction sector in the majority. It is seen that a contraction started in the construction sector in 2014 and this contraction continued in 2015 as well (World, 2015). While the sector could not recover in 2016-2017, the sector most affected by the 2018 crisis was the construction sector (Habertürk, 2019). In addition, due to the contraction in the sector in 2019, the production of the construction materials industry decreased (IMSAD, 2020). As it is understood, the downward trend that started in 2014 continued until 2019.

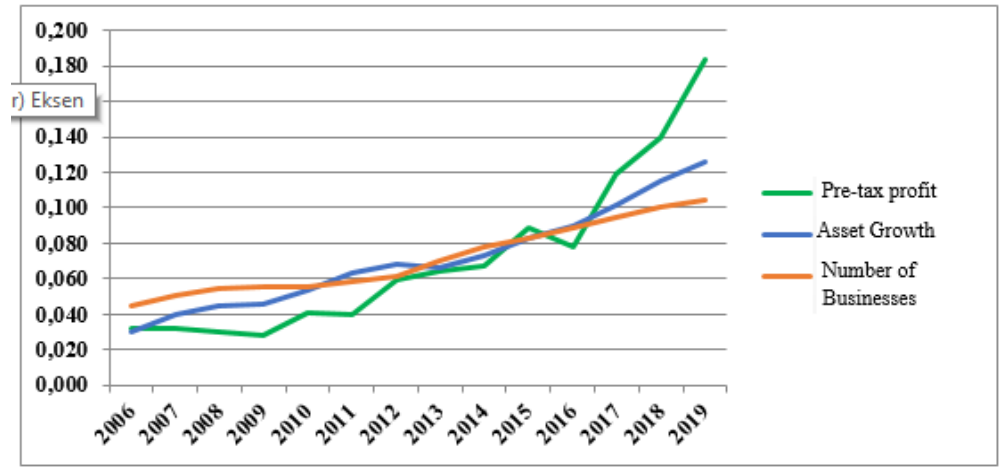

Figure 8: Trend Curves for the Fabricated Metal Products Industry Between 2006-2019

When the graphic above regarding the Fabricated Metal Products sector is examined; As in other sectors, the effects of the financial breaks in 2008, 2011 and 2013 are visible, albeit slightly. However, there was a partial decrease in 2016 and it was determined that the growth trend continued in the following years.

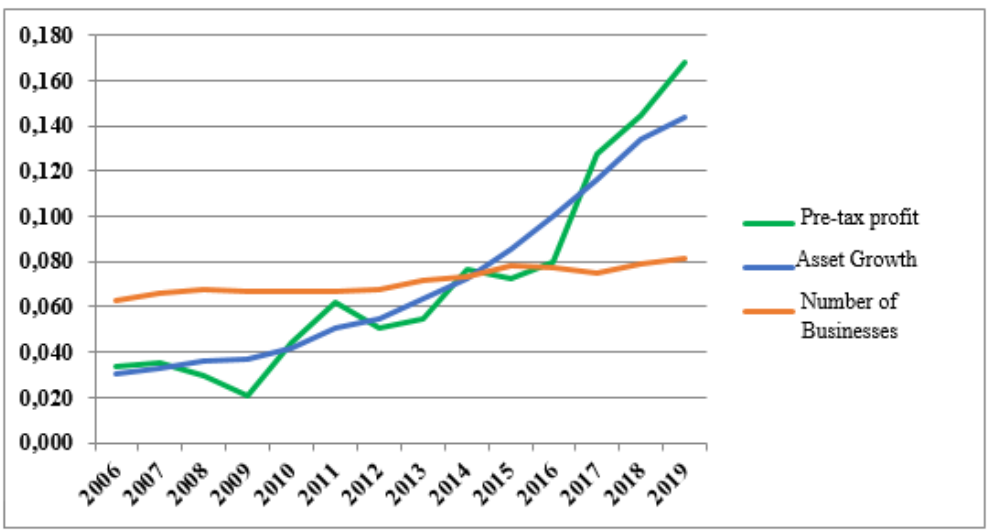

Figure 9: Trend Curves for the Automotive Industry Between 2006-2019

When the figure above regarding the automotive sector is examined; It was observed that there was a serious upward trend between the years mentioned and this trend experienced a break in 2008, 2011-2013 and 2016, as in other sectors. 


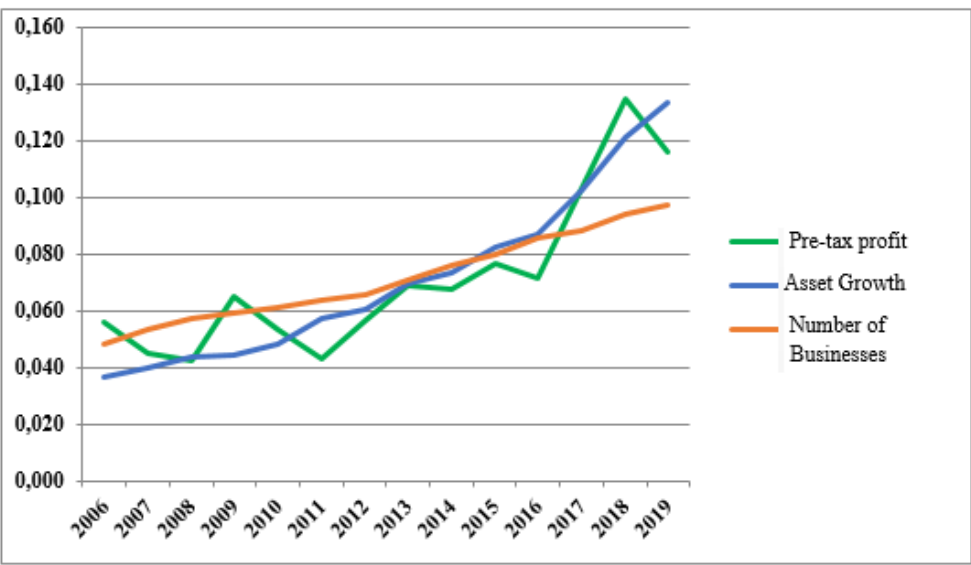

Figure 10: Trend Curves for the Electrical Appliances Industry Between 2006-2019

When the graphic above regarding the Electrical Appliances sector is examined; As in other sectors, the effect of the breaks in 2008 and 2011 can be seen. It was observed that the sector, which followed a partially horizontal course between 2013-2016 in terms of profitability, started a serious rise in 2017.

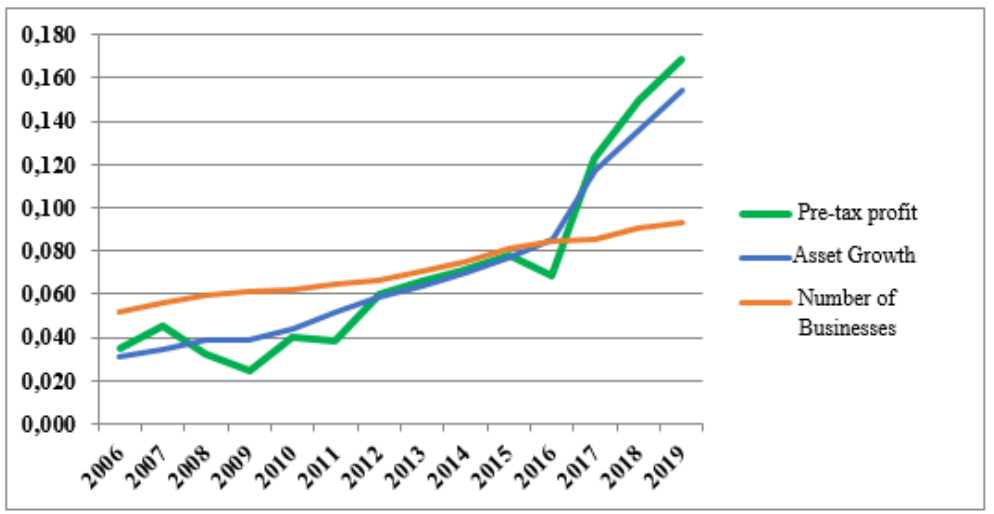

Figure 11: Trend Curves for the Machinery Industry Between 2006-2019

When the chart above regarding the machinery sector is examined; It is seen that there was an upward trend between the mentioned years and this trend experienced breaks in 2008 and 2011, as in other sectors. While an increase in line with the trend was observed between 2012 and 2015, it can be said that the trend is upwards in 2016.

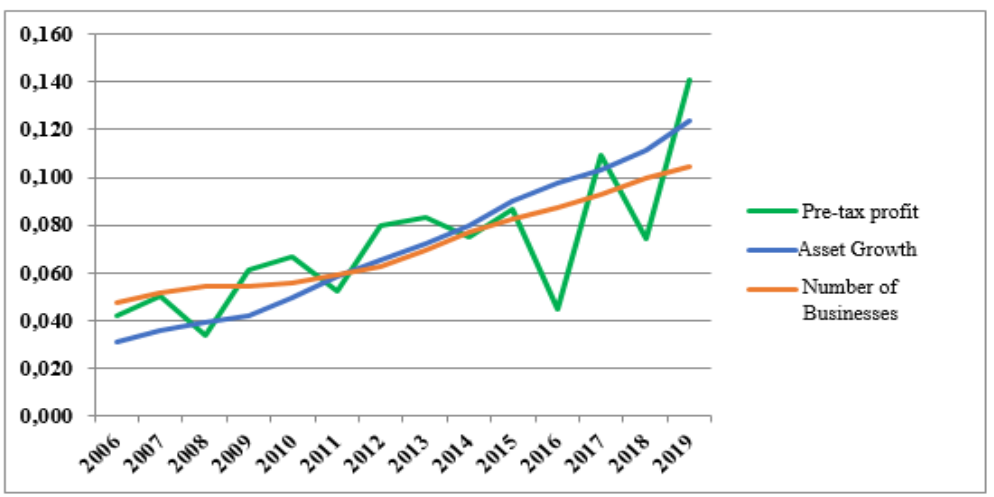

Figure 12: Trend Curves of the Furniture Industry Between 2006-2019

When the figure above regarding the furniture sector is examined; With the trend being constantly up, it is seen that there are sharp breaks in profitability in 2008, 2011, 2016 and 2018. A similar situation to the leather industry has been identified, especially in the examination made for the sector in 2016. Because it can be said that most of the furniture exports are made to Russia, and that the aircraft crisis affected the exports seriously. That is, while 100 million dollars of furniture exports were made to Russia in 2013, this figure decreased to 16 million dollars in 2016 (TOBB, 2017: 26). In addition, while there was an increase in profitability again at the end of 2016, it is seen that this increase was interrupted in 2018 , as in many sectors. 


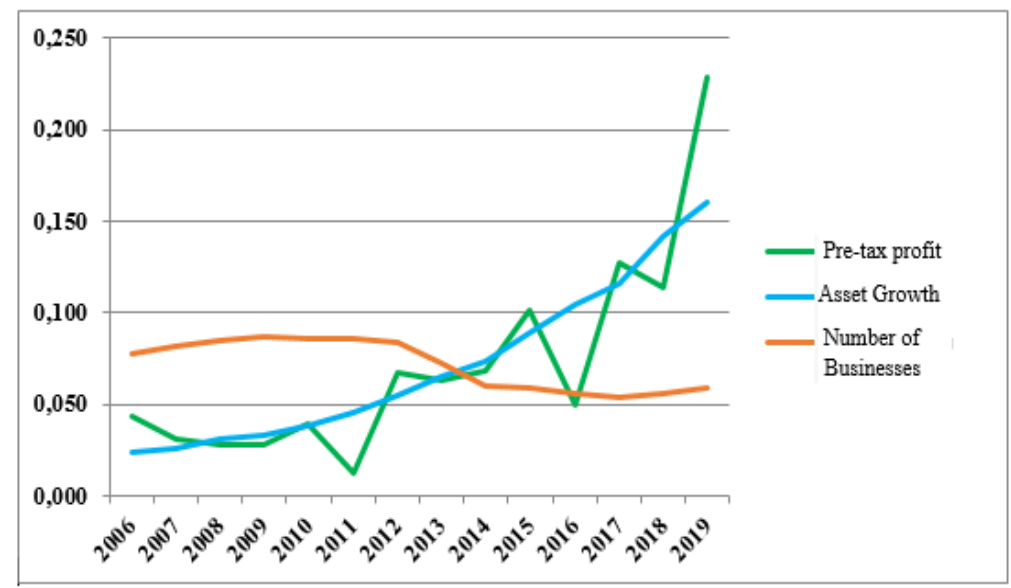

Figure 13: Trend Curves for Other Manufacturing Sector Between 2006-2019

When the graphic above regarding the Other Manufacturing sector is examined; Although it has similar characteristics with the previously evaluated sectors in terms of profitability and asset sizes, it is noteworthy that the change in the number of enterprises in the sector is not similar to any other sector. In terms of profitability, while an upward trend is observed in the sector, it is understood that there were sharp breaks in 2011 and 2016. It can be thought that the reason for these breaks is due to the reasons explained in the previous sectors. The decrease in the number of businesses operating in the sector after 2012 needs to be examined separately.

\subsection{Forecasts Based on Findings of Regression Equations}

In this section, it has been tried to make predictions about the years 2020-2023, based on the data of the year 20062019. Estimates expressed are based on Regression equations. Minitab and C + programs were used in the process of performing these calculations.

Table 5: Near Future Estimates of Net Profit Before Tax Data

\begin{tabular}{|c|c|c|c|c|c|c|c|c|c|c|c|c|}
\hline & 8 & 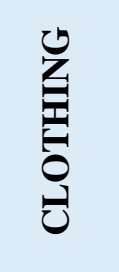 & 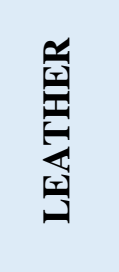 & 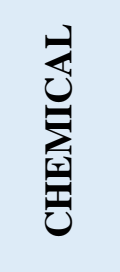 & $\underset{\mathrm{U}}{\mathrm{U}}$ & 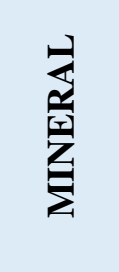 & $\underset{\sum}{\sum}$ & 党 & $\underset{z}{\frac{1}{Z}}$ & $\sum_{0}^{\frac{1}{2}}$ & 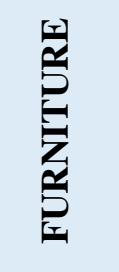 & 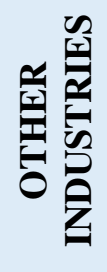 \\
\hline 2007 & $\% 239,21$ & $\% 23,99$ & $\% 5,40$ & $\% 9,55$ & $\% 17,23$ & $\% 3,79$ & $\% 1,06$ & $-\% 19,49$ & $\% 28,75$ & $\% 4,95$ & $\% 19,48$ & $-\% 28,47$ \\
\hline 2008 & $-\% 75,60$ & $-\% 56,32$ & $-\% 33,64$ & $-\% 36,19$ & $-\% 58,59$ & $-\% 50,89$ & $-\% 8,17$ & $-\% 6,01$ & $-\% 29,21$ & $-\% 14,92$ & $-\% 32,84$ & $-\% 10,08$ \\
\hline 2009 & $\% 257,82$ & $\% 145,49$ & $\% 37,91$ & $\% 83,04$ & $\% 159,06$ & $-\% 5,62$ & $-\% 5,06$ & $\% 53,94$ & $-\% 22,68$ & $-\% 29,26$ & $\% 82,52$ & $\% 2,60$ \\
\hline 2010 & $-\% 9,31$ & $\% 29,42$ & $\% 51,94$ & $\% 49,11$ & $\% 3,99$ & $\% 67,14$ & $\% 43,94$ & $-\% 17,57$ & $\% 61,91$ & $\% 109,79$ & $\% 8,69$ & $\% 37,45$ \\
\hline 2011 & $-\% 42,09$ & $-\% 69,92$ & $-\% 41,71$ & $-\% 23,51$ & $-\% 25,94$ & $-\% 21,19$ & $-\% 2,00$ & $-\% 20,06$ & $-\% 4,11$ & $\% 40,89$ & $-\% 21,80$ & $-\% 68,34$ \\
\hline 2012 & $\% 105,78$ & $\% 257,83$ & $\% 88,20$ & $\% 124,58$ & $\% 91,78$ & $\% 33,16$ & $\% 49,15$ & $\% 32,47$ & $\% 56,67$ & $-\% 18,30$ & $\% 52,77$ & $\% 444,06$ \\
\hline 2013 & $-\% 39,84$ & $-\% 2,59$ & $\% 5,37$ & $-\% 10,49$ & $-\% 30,41$ & $\% 22,45$ & $\% 8,40$ & $\% 21,02$ & $\% 9,21$ & $\% 7,83$ & $\% 4,66$ & $-\% 5,59$ \\
\hline 2014 & $\% 68,19$ & $\% 7,52$ & $-\% 12,86$ & $\% 57,76$ & $\% 66,30$ & $\% 42,71$ & $\% 4,56$ & $-\% 1,78$ & $\% 7,80$ & $\% 40,11$ & $-\% 10,50$ & $\% 7,73$ \\
\hline 2015 & $-\% 12,33$ & $\% 28,82$ & $\% 20,77$ & $-\% 11,45$ & $-\% 0,97$ & $-\% 1,72$ & $\% 31,84$ & $\% 12,99$ & $\% 10,54$ & $-\% 4,94$ & $\% 15,79$ & $\% 48,55$ \\
\hline 2016 & $\% 14,97$ & $-\% 37,28$ & $-\% 44,73$ & $\% 14,94$ & $\% 9,72$ & $-\% 15,17$ & $-\% 11,38$ & $-\% 6,24$ & $-\% 12,08$ & $\% 9,99$ & $-\% 48,18$ & $-\% 51,16$ \\
\hline 2017 & $\% 56,40$ & $\% 139,00$ & $\% 179,68$ & $\% 130,06$ & $\% 59,46$ & $-\% 6,06$ & $\% 51,78$ & $\% 43,52$ & $\% 78,89$ & $\% 59,35$ & $\% 143,61$ & $\% 158,09$ \\
\hline 2018 & $-\% 46,36$ & $\% 11,25$ & $-\% 58,15$ & $\% 5,24$ & $\% 12,67$ & $-\% 41,81$ & $\% 17,27$ & $\% 31,06$ & $\% 21,78$ & $\% 13,00$ & $-\% 32,06$ & $-\% 10,74$ \\
\hline 2019 & $\% 235,88$ & $\% 27,85$ & $\% 184,61$ & $\% 13,83$ & $\% 36,36$ & $-\% 42,06$ & $\% 31,47$ & $-\% 13,72$ & $\% 12,18$ & $\% 16,31$ & $\% 89,73$ & $\% 100,89$ \\
\hline 2020 & $-\% 39,98$ & $-\% 21,47$ & $-\% 28,20$ & $-\% 14,35$ & $-\% 23,17$ & $\% 154,48$ & $-\% 19,38$ & $-\% 2,24$ & $-\% 15,32$ & $-\% 13,83$ & $-\% 22,54$ & $-\% 33,80$ \\
\hline 2021 & $\% 5,75$ & $\% 6,67$ & $\% 4,94$ & $\% 8,00$ & $\% 6,92$ & $\% 1,11$ & $\% 6,88$ & $\% 4,95$ & $\% 6,64$ & $\% 6,75$ & $\% 4,60$ & $\% 7,05$ \\
\hline 2022 & $\% 5,44$ & $\% 6,26$ & $\% 4,71$ & $\% 7,40$ & $\% 6,47$ & $\% 1,10$ & $\% 6,44$ & $\% 4,72$ & $\% 6,23$ & $\% 6,32$ & $\% 4,40$ & $\% 6,58$ \\
\hline 2023 & $\% 5,16$ & $\% 5,89$ & $\% 4,49$ & $\% 6,89$ & $\% 6,08$ & $\% 1,09$ & $\% 6,05$ & $\% 4,50$ & $\% 5,86$ & $\% 5,95$ & $\% 4,21$ & $\% 6,18$ \\
\hline
\end{tabular}

When the data in Table 5 is examined; As explained in the previous sections, it is seen that the sectors experienced serious profit decreases in 2008, 2011 and 2018. When Regression Analysis is performed with the data for the years 2006-2019, it is estimated that the profitability will decrease significantly in 2020 , but there will be a partial recovery in the following years. 
Table 6: Near Future Estimates of Asset Size Data

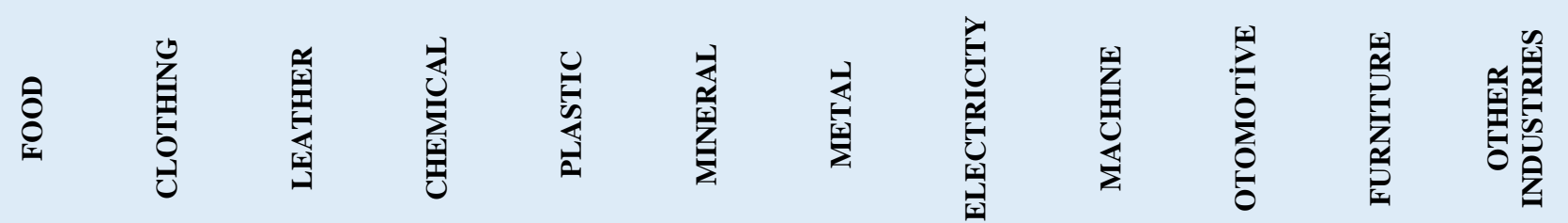

\begin{tabular}{|c|c|c|c|c|c|c|c|c|c|c|c|c|}
\hline 2007 & $\% 4,69$ & $\% 1,31$ & $\% 6,85$ & $\% 6,94$ & $\% 4,53$ & $\% 6,24$ & $\% 34,25$ & $\% 8,58$ & $\% 9,86$ & $\% 6,27$ & $\% 15,75$ & $\% 13,13$ \\
\hline 2008 & $\% 12,67$ & $\% 6,94$ & $\% 8,40$ & $\% 31,21$ & $\% 10,74$ & $\% 12,58$ & $\% 11,19$ & $\% 9,87$ & $\% 11,41$ & $\% 11,86$ & $\% 9,77$ & $\% 15,96$ \\
\hline 2009 & $\% 4,35$ & $\% 10,17$ & $\% 4,63$ & $\% 5,84$ & $\% 3,84$ & $\% 0,28$ & $\% 2,99$ & $\% 1,14$ & $\% 0,70$ & $\% 2,32$ & $\% 6,63$ & $\% 7,89$ \\
\hline 2010 & $\% 12,38$ & $\% 19,05$ & $\% 18,95$ & $\% 15,25$ & $\% 13,11$ & $\% 12,75$ & $\% 16,77$ & $\% 8,56$ & $\% 13,45$ & $\% 11,67$ & $\% 18,89$ & $\% 15,41$ \\
\hline 2011 & $\% 14,47$ & $\% 10,47$ & $\% 23,69$ & $\% 21,88$ & $\% 20,03$ & $\% 15,30$ & $\% 17,40$ & $\% 19,20$ & $\% 17,16$ & $\% 21,43$ & $\% 17,79$ & $\% 21,12$ \\
\hline 2012 & $\% 7,61$ & $\% 8,89$ & $\% 9,39$ & $\% 10,41$ & $\% 8,13$ & $\% 9,64$ & $\% 7,84$ & $\% 5,86$ & $\% 13,80$ & $\% 8,85$ & $\% 11,22$ & $\% 18,71$ \\
\hline 2013 & $\% 1,67$ & $\% 12,76$ & $\% 15,56$ & $\% 10,96$ & $\% 15,54$ & $\% 12,66$ & $-\% 3,40$ & $\% 14,76$ & $\% 8,36$ & $\% 16,43$ & $\% 10,18$ & $\% 19,53$ \\
\hline 2014 & $\% 8,26$ & $\% 7,45$ & $\% 11,12$ & $\% 16,39$ & $\% 8,45$ & $\% 14,26$ & $\% 11,20$ & $\% 5,88$ & $\% 10,05$ & $\% 14,12$ & $\% 10,77$ & $\% 13,46$ \\
\hline 2015 & $\% 10,12$ & $\% 11,20$ & $\% 162,74$ & $\% 20,64$ & $\% 12,60$ & $\% 17,05$ & $\% 13,12$ & $\% 12,12$ & $\% 10,35$ & $\% 17,54$ & $\% 12,66$ & $\% 20,24$ \\
\hline 2016 & $\% 10,94$ & $\% 4,70$ & $-\% 49,96$ & $\% 10,45$ & $\% 15,85$ & $\% 10,81$ & $\% 8,45$ & $\% 5,52$ & $\% 10,55$ & $\% 16,91$ & $\% 8,40$ & $\% 17,52$ \\
\hline 2017 & $\% 17,62$ & $\% 8,93$ & $\% 10,53$ & $\% 24,76$ & $\% 18,63$ & $\% 6,94$ & $\% 13,23$ & $\% 17,87$ & $\% 37,82$ & $\% 16,28$ & $\% 5,88$ & $\% 11,25$ \\
\hline 2018 & $\% 13,68$ & $\% 15,95$ & $\% 14,27$ & $\% 37,59$ & $\% 14,03$ & $\% 9,62$ & $\% 12,75$ & $\% 18,23$ & $\% 15,59$ & $\% 15,24$ & $\% 7,91$ & $\% 22,09$ \\
\hline 2019 & $\% 13,71$ & $\% 9,30$ & $\% 6,04$ & $\% 16,69$ & $\% 11,00$ & $\% 7,11$ & $\% 10,00$ & $\% 9,95$ & $\% 13,58$ & $\% 7,15$ & $\% 10,77$ & $\% 12,78$ \\
\hline 2020 & $-\% 8,22$ & $-\% 2,50$ & $\% 12,63$ & $-\% 15,97$ & $-\% 6,20$ & $\% 0,85$ & $-\% 3,36$ & $-\% 6,72$ & $-\% 11,21$ & $-\% 3,88$ & $\% 1,49$ & $-\% 7,15$ \\
\hline 2021 & $\% 5,49$ & $\% 5,50$ & $\% 6,34$ & $\% 7,08$ & $\% 6,20$ & $\% 5,79$ & $\% 5,52$ & $\% 5,68$ & $\% 6,38$ & $\% 6,44$ & $\% 5,73$ & $\% 6,91$ \\
\hline 2022 & $\% 5,20$ & $\% 5,21$ & $\% 5,97$ & $\% 6,61$ & $\% 5,84$ & $\% 5,48$ & $\% 5,23$ & $\% 5,37$ & $\% 5,99$ & $\% 6,05$ & $\% 5,42$ & $\% 6,47$ \\
\hline 2023 & $\% 4,95$ & $\% 4,95$ & $\% 5,63$ & $\% 6,20$ & $\% 5,51$ & $\% 5,19$ & $\% 4,97$ & $\% 5,10$ & $\% 5,65$ & $\% 5,71$ & $\% 5,14$ & $\% 6,07$ \\
\hline
\end{tabular}

When the data in Table 6 is examined; In terms of asset size, it is seen that the Turkish Manufacturing Industry is in an upward trend between 2006-2019. However, it is noteworthy that this growth trend slowed down active growth after years of decline in profitability such as 2008 and 2011 (especially 2009 and 2012). In addition, it is seen that the most serious shrinkage was experienced in the leather sector in 2016. It can be said that this is due to the plane crisis with Russia, as explained in the previous sections. It is seen that the estimations made in terms of asset size for the coming years display a similar appearance to the profitability level. In other words, it is estimated that the sectors will experience shrinkage in terms of asset size in 2020 and will increase slightly in the following years.

Table 7: Near Future Estimates of the Data on the Number of Businesses
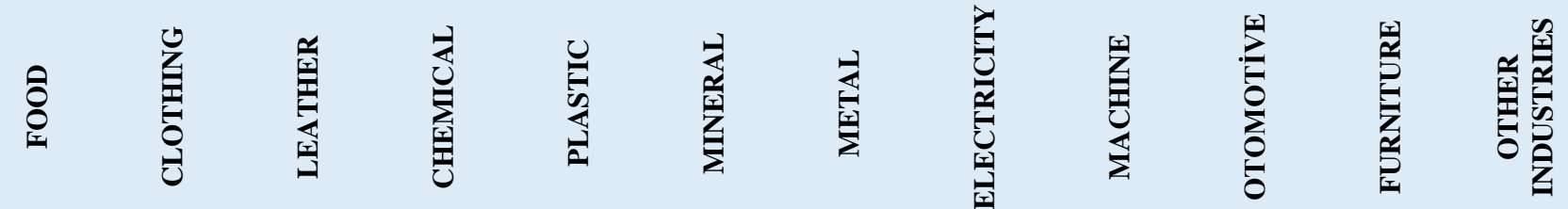

\begin{tabular}{|c|c|c|c|c|c|c|c|c|c|c|c|c|}
\hline 2007 & $\% 15,59$ & $\% 7,74$ & $\% 3,94$ & $\% 2,81$ & $\% 14,58$ & $\% 16,32$ & $\% 12,83$ & $\% 10,18$ & $\% 9,14$ & $\% 5,67$ & $\% 8,36$ & $\% 5,43$ \\
\hline 2008 & $\% 5,64$ & $\% 3,95$ & $\% 0,72$ & $-\% 1,23$ & $\% 8,30$ & $\% 5,26$ & $\% 7,93$ & $\% 7,35$ & $\% 5,53$ & $\% 1,70$ & $\% 4,51$ & $\% 3,83$ \\
\hline 2009 & $\% 5,78$ & $-\% 1,25$ & $-\% 0,75$ & $-\% 1,44$ & $\% 3,59$ & $\% 2,45$ & $\% 3,24$ & $\% 3,80$ & $\% 3,38$ & $-\% 0,93$ & $\% 1,13$ & $\% 2,61$ \\
\hline 2010 & $\% 3,40$ & $-\% 1,38$ & $-\% 1,62$ & $\% 0,15$ & $\% 3,92$ & $\% 0,64$ & $-\% 0,13$ & $\% 3,55$ & $\% 1,57$ & $-\% 0,26$ & $\% 2,41$ & $-\% 1,84$ \\
\hline 2011 & $\% 3,29$ & $\% 3,01$ & $\% 3,42$ & $\% 2,04$ & $\% 4,44$ & $\% 2,28$ & $\% 4,72$ & $\% 4,03$ & $\% 4,14$ & $\% 0,23$ & $\% 5,13$ & $\% 0,01$ \\
\hline 2012 & $\% 3,35$ & $\% 3,40$ & $\% 4,67$ & $-\% 0,40$ & $\% 3,04$ & $\% 2,83$ & $\% 5,66$ & $\% 3,30$ & $\% 2,60$ & $\% 1,04$ & $\% 6,75$ & $-\% 1,67$ \\
\hline 2013 & $\% 8,77$ & $\% 7,23$ & $\% 1,61$ & $-\% 0,11$ & $\% 3,26$ & $\% 5,63$ & $\% 14,11$ & $\% 7,20$ & $\% 6,28$ & $\% 5,76$ & $\% 10,97$ & $-\% 14,40$ \\
\hline 2014 & $\% 7,10$ & $\% 6,62$ & $\% 3,83$ & $-\% 1,48$ & $\% 4,92$ & $\% 2,55$ & $\% 10,50$ & $\% 8,03$ & $\% 6,66$ & $\% 2,49$ & $\% 10,24$ & $-\% 16,45$ \\
\hline 2015 & $\% 3,53$ & $\% 4,23$ & $\% 4,31$ & $\% 1,22$ & $\% 4,82$ & $\% 6,98$ & $\% 7,04$ & $\% 4,62$ & $\% 7,59$ & $\% 7,00$ & $\% 7,37$ & $-\% 1,67$ \\
\hline 2016 & $\% 6,16$ & $\% 3,10$ & $\% 4,92$ & $\% 3,37$ & $\% 4,12$ & $\% 1,91$ & $\% 6,95$ & $\% 7,41$ & $\% 4,22$ & $-\% 1,30$ & $\% 6,02$ & $-\% 5,20$ \\
\hline 2017 & $\% 6,22$ & $\% 7,66$ & $\% 0,78$ & $-\% 2,56$ & $\% 4,55$ & $\% 3,19$ & $\% 6,06$ & $\% 3,29$ & $\% 1,78$ & $-\% 3,18$ & $\% 6,22$ & $-\% 3,88$ \\
\hline 2018 & $\% 5,13$ & $\% 5,77$ & $\% 4,33$ & $\% 6,32$ & $\% 4,89$ & $\% 3,66$ & $\% 5,92$ & $\% 6,37$ & $\% 5,61$ & $\% 5,14$ & $\% 6,87$ & $\% 2,99$ \\
\hline 2019 & $\% 5,16$ & $\% 7,57$ & $\% 4,57$ & $\% 3,38$ & $\% 2,27$ & $\% 0,89$ & $\% 4,68$ & $\% 3,46$ & $\% 2,52$ & $\% 3,12$ & $\% 5,40$ & $\% 5,36$ \\
\hline 2020 & $\% 1,23$ & $-\% 4,01$ & $-\% 1,81$ & $-\% 4,53$ & $\% 3,24$ & $\% 3,84$ & $\% 1,79$ & $\% 2,07$ & $\% 2,73$ & $\% 0,06$ & $\% 0,27$ & $-\% 12,99$ \\
\hline 2021 & $\% 3,82$ & $\% 3,13$ & $\% 2,19$ & $\% 0,54$ & $\% 3,29$ & $\% 2,79$ & $\% 4,40$ & $\% 3,75$ & $\% 3,35$ & $\% 1,61$ & $\% 4,27$ & $-\% 5,41$ \\
\hline 2022 & $\% 3,68$ & $\% 3,04$ & $\% 2,15$ & $\% 0,54$ & $\% 3,18$ & $\% 2,71$ & $\% 4,21$ & $\% 3,61$ & $\% 3,24$ & $\% 1,58$ & $\% 4,09$ & $-\% 5,72$ \\
\hline 2023 & $\% 3,54$ & $\% 2,95$ & $\% 2,10$ & $\% 0,54$ & $\% 3,08$ & $\% 2,64$ & $\% 4,04$ & $\% 3,49$ & $\% 3,14$ & $\% 1,56$ & $\% 3,93$ & $-\% 6,07$ \\
\hline
\end{tabular}

When the data in Table 7 is examined; Similar estimation situations such as profitability and asset size are observed in terms of the number of enterprises in all sectors. In other words, it is understood that there was an upward trend in the number of enterprises in the Turkish Manufacturing Industry in the said years, this trend slowed down during the crisis periods but did not experience serious breaks. However, it is understood that there is a very different situation in the other manufacturing sector. More detailed financial data is needed to determine the actual matter.

\section{RESULT AND CONCLUSION}

In this study, it is aimed to investigate the existence of systematic manipulations in the mentioned years and to make predictions for the near future, taking into account the basic financial data obtained from the financial statements of 
the Turkish Manufacturing Sector for the years 2006-2019 and the number of enterprises in the sectors. In one aspect, the financial performances of the manufacturing sector enterprises in the globalizing world conditions between the years 2006-2019 were evaluated.

First, the Mann Kendal analysis on the data set of the study was applied, and with this analysis, the existence of a systematic trend in terms of profit before tax, asset size and the number of businesses operating in the sectors between 2006-2019 was investigated. As a result of the analysis, it was concluded that there was no systematic trend. In other words, it was determined that the data based on the said years were not systematically affected by a temporal cycle.

However, by creating the regression equations and observing the slope measures, differences in the decreasing or increasing trends of the sectors in the mentioned years were determined. While it was determined that there was an upward trend in the majority of the examined sectors, it was observed that there was a downward trend in the chemical, mineral and other manufacturing sectors.

In addition, within the framework of the findings, it was understood that the global and national economic breaks experienced in 2008, 2011 and 2018 seriously affected the manufacturing sector. This result is compatible with other academic studies on the subject.

In the last part of the study, financial forecasts for the next 4 years (2020-2023) were tried to be made. According to these forecasts, a decrease in profitability and asset contraction are expected in the majority of sectors in 2020. However, the financial crisis that occurred with the COVID-19 global epidemic in 2020 has nothing to do with these forecasts. Research results predict that there will be an economic contraction in 2020, independent of COVID-19.

Different Trend Analysis methods, Forecasting Methods and Time Series Analysis Methods can be used in similar studies to be carried out in the future. In addition, different sectors and financial data can be taken into account. However, the timeframe of the studies can be narrower or wider.

\section{REFERENCES}

Avc1, Muhammet Ali, ve Harun Sulak (2015). "Kriz Dönemlerinde Ekonomik Büyüme Ile Seçilmiş Ekonomik Göstergeler Arasındaki İlişkilerin Regresyon Ağaçları ve EKK Yöntemi Ile İncelenmesi : Türkiye An Analysis of the Relationship Between 1990-2009 Period in Turkey.” Finans Politik \& Ekonomik Yorumlar 52 (604): 29-42.

Büyükkaraciğan, N. (2019). "Hidrolojik Verilerin Değişkenlik Analizi ve Uygulamaları" IKKSAD Yayınları, Ankara

Cengiz, M. A. ve Terzi, Y. (2020). Korelasyon Analizi - Basit Doğrusal Regresyon Analizi, https://avys.omu.edu.tr > app > public > yukselt, (Erişim Tarihi: 16.05.2021)

Citakoğlu, Hatice ve Necmiye Minarecioğlu (2019). "Trend Analysis of Monthly Average Flows of Kızılırmak Basin.” Journal of Anatolian Environmental and Animal Sciences 4 (3): 435-40.

Çiçek, Hasan, ve Ilkay Doğan (2018). "Türkiye ' de Canlı Sığır ve Sı ̆̆ır Eti İthalatındaki Gelişmeler ve Üretici." Kocatepe Veterinary Journal 11 (1):1-10.

Dalkılıç, Hüseyin Yıldırım (2019). "Yağışların Trend Analizi.” Erzincan Üniversitesi Fen Bilimleri Enstitüsü Dergisi 12 (3):1537-49.

Durana, Pavol ve Radovan Bacik (2020). "Earnings Management: Local or Global Phenomenon in the Visegrad Four?" SHS Web of Conferences 92: 02015.

Ercan, Cuma ve Şenbayram, Emel Aba (2018). "Bist’te Seçilmiş Bir İşletme Üzerinde Trend Analizi Uygulaması: Tarım Sektörü Örneği.” 3. Uluslararas1 El Ruha Sosyal Bilimler Kongresi. 2-3-4 Kasım,2018, 324-333

Gujarati, Damodar (çev. Ümit Şenesen, Gülay Günlük Şenesen) (2008) "Temel Ekonometri", Literatür Yayınları

Güngörmüş, Ali Haydar (2007). "Emet Belediyesinde Muhasebe Bilgilerinin Finansal Analiz Teknikleri İçinde Yer Alan Eğilim Yüzdeleri Yöntemi İle Bilgi Amaçlı Olarak Kullanılması.” İzmir Serbest Muhasebeci Mali Müşavirler Odası Dayanışma Dergisi 98: 27-33.

Hirsch, R.M., vd. (1991). "Selection of methods for the detection and estimation of trends in water quality", Water Resources Research 27 (5), 803-813.

Karabulut, Murat, ve Cosun Fatma (2007). "Kahramanmaraş İlinde Yağışların Trend Analizi.” Coğrafi Bilimler Dergisi, 7 (1): 65-83

Kliestik, Tomas, vd. (2020). "Advanced Methods of Earnings Management: Monotonic Trends and Change-Points under Spotlight in the Visegrad Countries." Oeconomia Copernicana 11(2): 371-400. 
Kiracı, Kasım, ve Karaaslan, İbrahim (2015). "Seçilmiş Havayolu İşletmelerine Yönelik Trend Analizi Uygulaması Araş.” 1. Uluslararası Ekonomi ve İşletme Kongresi (ICEB'15). 10-14

Özgülbaş, Nermin (2006). "Türkiye'de Kamu Hastanelerinin Finansal Durum Değerlendirmede Kullanılabilecekleri Bir Yöntem: Trend Analizi.” Muhasebe ve Finansman Dergisi 29:129-39.

Saplığlu, Kemal vd. (2018). "Somali’nin Somaliland Bölgesi Yağışlarının Trend Analizi.” Gümüşhane Üniversitesi Fen Bilimleri Enstitüsü Dergisi 8:48-62.

Sargut, Fadime (2018). “Trend Analizi Yöntemi İle Ereğli Demir Çelik Fabrikasının Finansal Tablo Analizi” Göller Bölgesi Aylık Hakemli Ekonomi ve Kültür Dergisi, 5:69-74.

Terzi, Özlem ve İlker, Ahmet (2020). "Kızılırmak Havzası'nda Sıcaklık Değerlerinin Trend Analizi.” Süleyman Demirel Üniversitesi Fen Bilimleri Enstitüsü Dergisi. 24 (3) 626-34.

TOBB (2017), “Türkiye Mobilya Ürünleri Meclisi Sektör Raporu”, TOBB Yayın No: 2018/304

Usta, Öcal (2008). "İşletme Finansı ve Finansal Yönetim". Detay Yayınları.

Valášková, Katarína vd. (2020). "Alter Ego Only Four Times? The Case Study of Business Profits in the Visegrad Group.” E\&M Economics and Management 23(3):101-19.

Yavuz, A. (2020) Zaman Serisi Analizleri, http://www.mku.edu.tr/files/339-8868446a-e4c0-4070-8530b8beccc1b0ec.pdf, (Erişim Tarihi: 16.05.2021)

Yıldırım, Zerife, ve Birecikli, Şenay Üçdoruk (2021). "Dilim Regresyon Yöntemiyle Türkiye'de Hanehalkı Tasarruf Eğilimi Araştırması.” Atatürk Üniversitesi İktisadi ve İdari Bilimler Dergisi 35(2):523-50.

Yue, S. vd. (2002). "Power of the Mann- Kendall and Spearman's Rho Tests for Detecting Monotonic Trends in Hydrological series". Journal of Hydrology, 259, 254-271.

Yu, Y.S. vd. (1993). "Non-Parametric Trend Analysis of Water Quality Data of Rivers in Kansas". Journal of Hydrology, 150, 61-80.

https://productphilosophy.com/zaman-serisi-analizi/.Zaman Serisi Analizi, (Erişim Tarihi: 16.05.2021)

https://www.imsad.org/Uploads/Files/Turkiye_IMSAD_Subat2020_Sektor_Raporu.pdf (Erişim Tarihi, 15.05.2021)

https://www.haberturk.com/insaat-sektorunde-kuculme-dipten-donmeye-basladi-2545911-ekonomi (Erişim Tarihi: 15.05.2021)

https://haberrus.ru/economics/2015/12/19/rusya-krizi-deri-sektorunu-derinden-etkileyecek.html (Erişim Tarihi: 15.05.2021)

\section{EKLER}

Ek 1: Sektördeki Firmaların Ortalama Vergi Öncesi Kârlarına Ait Temel Veri Seti

\begin{tabular}{|c|c|c|c|c|c|c|c|c|c|c|c|c|}
\hline & GIDA & GIYYiM & DERÍ & KİMYASAL & PLASTÍK & MINERAL & METAL & ELEKTRIKK & MAKİNA & OTOMOTIV & MOBILLYA & DİĞER İMALAT \\
\hline 2006 & 71.516 & 48.646 & 46.452 & 199.823 & 123.609 & 440.521 & 71.628 & 431.546 & 147.538 & 613.248 & 41.739 & 36.672 \\
\hline 2007 & 242.590 & 60.317 & 48.961 & 218.914 & 144.909 & 457.207 & 72.389 & 347.454 & 189.956 & 643.611 & 49.871 & 26.233 \\
\hline 2008 & 59.194 & 26.344 & 32.488 & 139.688 & 60.003 & 224.546 & 66.472 & 326.577 & 134.473 & 547.582 & 33.492 & 23.590 \\
\hline 2009 & 211.806 & 64.674 & 44.805 & 255.684 & 155.445 & 211.934 & 63.111 & 502.717 & 103.977 & 387.353 & 61.129 & 24.203 \\
\hline 2010 & 192.092 & 83.703 & 68.075 & 381.238 & 161.651 & 354.233 & 90.838 & 414.406 & 168.348 & 812.627 & 66.439 & 33.267 \\
\hline 2011 & 111.234 & 25.177 & 39.680 & 291.612 & 119.718 & 279.180 & 89.017 & 331.295 & 161.431 & 1.144 .937 & 51.953 & 10.533 \\
\hline 2012 & 228.897 & 90.090 & 74.677 & 654.917 & 229.593 & 371.743 & 132.773 & 4338.858 & 252.907 & 935.425 & 79.366 & 57.304 \\
\hline 2013 & 137.700 & 87.754 & 78.687 & 586.217 & 159.773 & 455.212 & 143.923 & 531.106 & 276.199 & 1.008 .641 & 83.066 & 54.099 \\
\hline 2014 & 231.591 & 94.355 & 68.568 & 924.814 & 265.705 & 649.651 & 150.490 & 521.658 & 297.746 & 1.413 .180 & 74.345 & 58.278 \\
\hline 2015 & 203.047 & 121.552 & 82.808 & 818.882 & 263.137 & 638.502 & 198.405 & 589.422 & 329.117 & 1.343 .372 & 86.085 & 86.571 \\
\hline 2016 & 233.440 & 76.241 & 45.770 & 941.248 & 288.726 & 541.634 & 175.836 & 552.623 & 289.370 & 1.477 .583 & 44.609 & 42.281 \\
\hline 2017 & 365.111 & 182.215 & 128.009 & 2.165 .412 & 460.401 & 508.833 & 266.892 & 793.131 & 517.659 & 2.354 .566 & 108.671 & 109.123 \\
\hline 2018 & 195.855 & 202.709 & 53.574 & 2.278 .919 & 518.728 & 296.066 & 312.994 & 1.039 .513 & 630.389 & 2.660 .600 & 73.831 & 97.406 \\
\hline 2019 & 657.843 & 259.161 & 152.481 & 2.594 .085 & 707.317 & 171.542 & 411.486 & 896.887 & 707.181 & 3.094 .477 & 140.079 & 195.676 \\
\hline Minimum & 59.194 & 25.177 & 32.488 & 139.688 & 60.003 & 171.542 & 63.111 & 326.577 & 103.977 & 387.353 & 33.492 & 10.533 \\
\hline Maksimum & 657.843 & 259.161 & 152.481 & 2.594 .085 & 707.317 & 649.651 & 411.486 & 1.039 .513 & 707.181 & 3.094 .477 & 140.079 & 195.676 \\
\hline Ortalama & 224.423 & 101.639 & 68.931 & 889.390 & 261.337 & 400.057 & 160.447 & 551.228 & 300.449 & 1.316 .943 & 71.048 & 61.088 \\
\hline St. Sapma & 141.830 & 65.825 & 32.988 & 807.335 & 175.486 & 147.773 & 101.536 & 208.317 & 182.010 & 802.078 & 27.439 & 46.845 \\
\hline
\end{tabular}


Ek 2: Sektördeki Firmaların Ortalama Aktif Büyüklüğüne Ait Temel Veri Seti

\begin{tabular}{|c|c|c|c|c|c|c|c|c|c|c|c|c|}
\hline & Gida & Giyim & Deri & Kimyasal & Plastik & Mineral & Metal & Elektrik & Makina & Otomotiv & Mobilya & Diğer İmalatlar \\
\hline 2006 & 3.558 .210 & 1.548 .203 & "1.145.027 & 3.712 .548 & 2.452 .723 & "4.667.138 & "1.305.774 & "4.882.936 & 2.065 .900 & 7.163.264 & 900.712 & 757.684 \\
\hline 2007 & 3.725 .192 & 1.568 .425 & 1.223 .405 & 3.970 .367 & 2.563 .899 & 4.958 .583 & 1.752 .953 & 5.301 .913 & 2.269 .525 & 7.612 .293 & 1.042 .561 & 857.142 \\
\hline 2008 & 4.197 .073 & 1.677 .339 & 1.326 .126 & 5.209 .530 & 2.839 .328 & 5.582 .264 & 1.949 .056 & 5.825 .071 & 2.528 .499 & 8.515 .283 & 1.144 .441 & 993.956 \\
\hline 2009 & 4.379 .728 & 1.847 .980 & 1.387 .561 & 5.513 .897 & 2.948 .395 & 5.598 .032 & 2.007 .248 & 5.891 .766 & 2.546 .166 & 8.713 .071 & 1.220 .315 & 1.072 .421 \\
\hline 2010 & 4.922 .141 & 2.199 .995 & 1.650 .445 & 6.354 .630 & 3.334 .814 & 6.311 .969 & 2.343 .793 & 6.396 .349 & 2.888 .636 & 9.729 .683 & 1.450 .852 & 1.237 .668 \\
\hline 2011 & 5.634 .362 & 2.430 .304 & 2.041 .428 & 7.744 .810 & 4.002 .731 & 7.277 .523 & 2.751 .529 & 7.624 .565 & 3.384 .254 & 11.814 .777 & 1.708 .943 & 1.499 .059 \\
\hline 2012 & 6.063 .295 & 2.646 .463 & 2.233 .017 & 8.551 .014 & 4.328 .003 & 7.979 .358 & 2.967 .282 & 8.071 .381 & 3.851 .152 & 12.860 .434 & 1.900 .766 & 1.779 .472 \\
\hline 2013 & 6.164 .565 & 2.984 .209 & 2.580 .413 & 9.487 .827 & 5.000 .597 & 8.989 .580 & 2.866 .289 & 9.262 .446 & 4.173 .082 & 14.973 .120 & 2.094 .266 & 2.126 .982 \\
\hline 2014 & 6.673 .751 & 3.206 .670 & 2.867 .312 & 11.042 .893 & 5.422 .908 & 10.271 .513 & 3.187 .189 & 9.807 .260 & 4.592 .312 & 17.087 .935 & 2.319 .802 & 2.413 .179 \\
\hline 2015 & 7.349 .114 & 3.565 .925 & 7.533 .458 & 13.322 .530 & 6.106 .329 & 12.022 .914 & 3.605 .284 & 10.995 .787 & 5.067 .831 & 20.085 .922 & 2.613 .587 & 2.901 .609 \\
\hline 2016 & 8.152 .760 & 3.733 .455 & 3.769 .798 & 14.714 .567 & 7.074 .335 & 13.322 .309 & 3.909 .777 & 11.603 .166 & 5.602 .504 & 23.483 .058 & 2.833 .054 & 3.410 .068 \\
\hline 2017 & 9.589 .233 & 4.066 .949 & 4.166 .671 & 18.357 .451 & 8.392 .476 & 14.247 .362 & 4.427 .005 & 13.676 .915 & 7.721 .636 & 27.306 .088 & 2.999 .655 & 3.793 .691 \\
\hline 2018 & 10.901 .131 & 4.715 .485 & 4.761 .114 & 25.257 .445 & 9.570 .189 & 15.618 .573 & 4.991 .474 & 16.170 .195 & 8.925 .423 & 31.468 .842 & 3.236 .841 & 4.631 .803 \\
\hline 2019 & 12.395 .426 & 5.153 .996 & 5.048 .814 & 29.472 .567 & 10.622 .467 & 16.729 .021 & 5.490 .532 & 17.779 .064 & 10.137 .473 & 33.719 .218 & 3.585 .493 & 5.223 .940 \\
\hline Min. & 3.558 .210 & 1.548 .203 & 1.145 .027 & 3.712 .548 & 2.452 .723 & 4.667 .138 & 1.305 .774 & "4.882.936 & 2.065 .900 & 7.163 .264 & 900.712 & 757.684 \\
\hline Maks. & 12.395 .426 & 5.153 .996 & 7.533 .458 & 29.472 .567 & 10.622 .467 & 16.729 .021 & 5.490 .532 & 17.779 .064 & 10.137 .473 & 33.719 .218 & 3.585 .493 & 5.223 .940 \\
\hline Ort. & 6.693 .284 & 2.953 .243 & 2.981 .042 & 11.622 .291 & 5.332 .800 & 9.541 .153 & 3.111 .085 & 9.520 .630 & 4.696 .742 & 16.752 .356 & 2.075 .092 & 2.335 .620 \\
\hline St. S. & 2.623 .031 & 1.131 .207 & 1.799 .230 & 7.648 .644 & 2.586 .814 & 4.017 .912 & 1.203 .811 & 3.945 .550 & 2.474 .475 & 8.751 .896 & 845.437 & 1.402 .836 \\
\hline
\end{tabular}

Ek 3: Sektörlerdeki İşletme Sayılarına Ait Temel Veri Seti

\begin{tabular}{|c|c|c|c|c|c|c|c|c|c|c|c|c|}
\hline & 悹 & : & 중 & $\sum_{i}^{2}$ & 当 & $\underset{z}{z}$ & 氛 & 光 & $\frac{\pi}{z}$ & 를 & 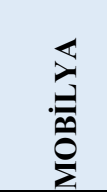 & 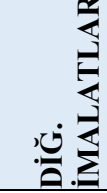 \\
\hline 2006 & 11.055 & 12.608 & 3.322 & 4.656 & 6.392 & 5.838 & 11.823 & 3.162 & 7.857 & 2.891 & 6.544 & 8.028 \\
\hline 2007 & 12.778 & 13.584 & 3.453 & 4.787 & 7.324 & 6.791 & 13.340 & 3.484 & 8.575 & 3.055 & 7.091 & 8.464 \\
\hline 2008 & 13.499 & 14.121 & 3.478 & 4.728 & 7.932 & 7.148 & 14.398 & 3.740 & 9.049 & 3.107 & 7.411 & 8.788 \\
\hline 2009 & 14.279 & 13.944 & 3.452 & 4.660 & 8.217 & 7.323 & 14.865 & 3.882 & 9.355 & 3.078 & 7.495 & 9.017 \\
\hline 2010 & 14.765 & 13.752 & 3.396 & 4.667 & 8.539 & 7.370 & 14.845 & 4.020 & 9.502 & 3.070 & 7.676 & 8.851 \\
\hline 2011 & 15.251 & 14.166 & 3.512 & 4.762 & 8.918 & 7.538 & 15.546 & 4.182 & 9.895 & 3.077 & 8.070 & 8.852 \\
\hline 2012 & 15.762 & 14.648 & 3.676 & 4.743 & 9.189 & 7.751 & 16.426 & 4.320 & 10.152 & 3.109 & 8.615 & 8.704 \\
\hline 2013 & 17.144 & 15.707 & 3.735 & 4.738 & 9.489 & 8.187 & 18.744 & 4.631 & 10.790 & 3.288 & 9.560 & 7.451 \\
\hline 2014 & 18.362 & 16.747 & 3.878 & 4.668 & 9.956 & 8.396 & 20.712 & 5.003 & 11.509 & 3.370 & 10.539 & 6.225 \\
\hline 2015 & 19.011 & 17.456 & 4.045 & 4.725 & 10.436 & 8.982 & 22.170 & 5.234 & 12.382 & 3.606 & 11.316 & 6.121 \\
\hline 2016 & 20.183 & 17.997 & 4.244 & 4.884 & 10.866 & 9.154 & 23.710 & 5.622 & 12.904 & 3.559 & 11.997 & 5.803 \\
\hline 2017 & 21.439 & 19.376 & 4.277 & 4.759 & 11.360 & 9.446 & 25.148 & 5.807 & 13.134 & 3.446 & 12.743 & 5.578 \\
\hline 2018 & 22.538 & 20.494 & 4.462 & 5.060 & 11.916 & 9.792 & 26.638 & 6.177 & 13.871 & 3.623 & 13.619 & 5.745 \\
\hline 2019 & 23.701 & 22.046 & 4.666 & 5.231 & 12.187 & 9.879 & 27.884 & 6.391 & 14.221 & 3.736 & 14.354 & 6.053 \\
\hline Minimum & 23.991 & 21.162 & 4.582 & 4.994 & 12.581 & 10.259 & 28.383 & 6.523 & 14.610 & 3.738 & 14.393 & 5.267 \\
\hline Maksimum & 24.907 & 21.825 & 4.682 & 5.021 & 12.995 & 10.545 & 29.632 & 6.768 & 15.099 & 3.798 & 15.007 & 4.982 \\
\hline Ortalama & 25.822 & 22.488 & 4.783 & 5.048 & 13.408 & 10.831 & 30.881 & 7.012 & 15.588 & 3.859 & 15.621 & 4.697 \\
\hline St. Sapma & 26.738 & 23.151 & 4.883 & 5.075 & 13.822 & 11.117 & 32.130 & 7.256 & 16.077 & 3.919 & 16.235 & 4.411 \\
\hline Toplam & 11.055 & 12.608 & 3.322 & 4.656 & 6.392 & 5.838 & 11.823 & 3.162 & 7.857 & 2.891 & 6.544 & 8.028 \\
\hline
\end{tabular}

